\title{
Genetic subdivision of the intertidal snail Bembicium vittatum (Gastropoda: Littorinidae) varies with habitat in the Houtman Abrolhos Islands, Western Australia
}

\author{
M. S. JOHNSON \& R. BLACK \\ Department of Zoology, The University of Western Australia, Nedlands, Western Australia 6009, Australia
}

\begin{abstract}
The littorine gastropod Bembicium vittatum has benthic egg masses and is thought to have little or no period of planktonic development. A study of allozyme polymorphisms in populations from the Houtman Abrolhos Islands, Western Australia, permitted examination of genetic subdivision within and among island groups, and among populations from contrasting habitats which occur throughout the Abrolhos archipelago. Across all populations, the average $F_{\mathrm{ST}}$ for five polymorphic loci was 0.163 , which is very large for a marine species but similar to values found for other gastropods that lack planktonic development. The level of genetic subdivision varied dramatically with habitat. Over similar distances, the average $F_{\text {ST }}$ among lake populations was 0.277 , compared with 0.138 among populations from protected lagoonal shores, and only 0.022 among populations from relatively exposed shores. This variation emphasizes the need to consider local conditions when attempting to determine the genetic structure of a species.
\end{abstract}

Keywords: gene flow, genetic subdivision, $F_{\mathrm{ST}}$, littorine snail.

\section{Introduction}

The amount of genetic subdivision within a species depends upon the interactions among natural selection, genetic drift, and gene flow. Gene flow among populations decreases the potential for genetic divergence due to either selection or drift. By retarding the accumulation of genetic differences, gene flow disrupts the development of localized adaptation. Similarly, by increasing effective population size, genetic connections among populations reduce both random fluctuations in allelic frequencies and the rate of loss of genetic variation due to sampling within finite local populations. Although it is fundamentally important, gene flow is not easily studied in natural populations. Measures of genetic subdivision are much easier to obtain. In addition to their descriptive value, such measures are being used increasingly to make inferences about the level of gene flow (Slatkin, 1985, 1987).

Questions about gene flow are particularly important in the marine environment, because the potential for connectedness among populations is great. Know- ledge of the extent of such connectedness is important both for the management of populations and for an understanding of evolutionary processes in the marine environment. Direct measurements of gene flow, however, are especially difficult to obtain for marine species. The extent of genetic connectedness depends upon the characteristics of the species and the environmental conditions. The duration of larval life has received much attention as a predictor of gene flow, and hence retardation of genetic divergence (Scheltema, 1971, 1978; Crisp, 1978). Studies of allozyme polymorphisms have generally confirmed the expected inverse relationship between genetic differentiation and the probable length of larval life (e.g. Berger, 1973; Janson, 1987; Waples, 1987), although some species with apparently a great potential for gene flow have a surprisingly large genetic subdivision (Burton, 1983; Hedgecock, 1986). Littorinid snails have provided some of the clearest examples of the greater localized genetic differentiation and adaptation in species which lack a planktonic phase of development (Berger, 1973; Janson, 1987; Knight et al., 1987; Behrens Yamada, 1989). 
Although the relationship between planktonic dispersal and reduced genetic differentiation has received much attention, less work has examined environmental effects on gene flow. As measures of genetic subdivision, such as Wright's (1978) $F_{\mathrm{ST}}$, are increasingly used to characterize species, it is especially important to take into account environmental effects on the potential for gene flow. For marine species, this includes the strength and direction of water currents, as well as potential barriers to movements of animals.

The littorinid snail Bembicium vittatum (formerly Bembicium melanostoma; see Reid, 1988) provides a good opportunity to examine the extent of genetic subdivision in the context of both life history and contrasting environmental conditions. This species lives on sheltered intertidal rocky shores and mangrove roots in South Australia and southern Western Australia. It lays egg masses on the shore, and has little or no planktonic development (Reid, 1988). Because of this mode of development, there is the potential for substantial genetic subdivision over relatively short distances.

At the northern end of its range in Western Australia, B. vittatum is widespread in the Houtman Abrolhos Islands. This archipelago includes a series of separate island groups, within each of which $B$. vittatum is found in contrasting areas of relatively exposed reef flats, calm lagoonal shores, and isolated lakes, which could be expected to affect the amount of gene flow. Because each of these habitats is found over the same distances, we have been able to use this heterogeneity to examine the spatial scale of genetic subdivision in $B$. vittatum associated with different environmental constraints to gene flow.

\section{Materials and methods}

\section{Samples}

Samples of $B$. vittatum were collected from rocky intertidal shores in the Houtman Abrolhos Islands in May, 1987 (Fig. 1). These islands cap the southernmost coral reef structures in the Indian Ocean, and are 70-100 km off the Western Australian coast. The Abrolhos archipelago consists of three carbonate platforms supporting groups of many low islands, each platform being $20-30 \mathrm{~km}$ in extent, and separated by deep channels $10-20 \mathrm{~km}$ wide (for a summary of the characteristics of the Abrolhos Islands, see Hatcher, 1985). Between two and 10 samples from intertidal shores were collected from each of the three major island groups, thus allowing assessment of genetic divergence within and among groups. Within each island group, the southwestern portion is most exposed, with broad reef flats being well developed in
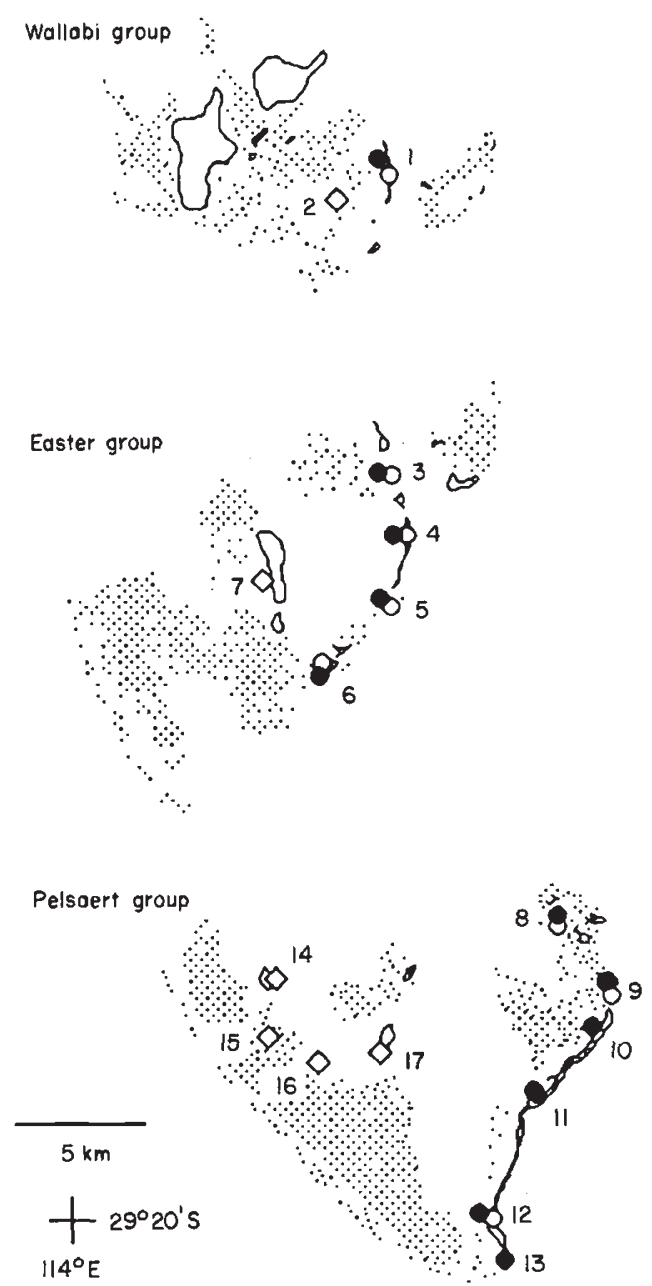

Fig. 1 Map showing collecting sites of Bembicium vittatum in the Houtman Abrolhos Islands, Western Australia. $(\bullet)$ Eastern shore sites; $(0)$ paired lake sites; $(\diamond)$ western shore sites. Stippled areas are reef flats. Names of the numbered locations are given in Table 1.

the Easter and Pelsaert groups (Fig. 1). Although the reefs protect the island shores occupied by $B$. vittatum from deep ocean waves, these western populations are exposed to local wind waves and substantial wind and wave-driven water currents from the western reef margins. In contrast, the eastern edge of each platform is lined with long, narrow islands, which have calm lagoonal environments on their western shores. Sites numbered 2, 7, and 14 to 17 (Fig. 1) were from the more exposed western portions of the archipelago, whereas the remaining shore sites were from the eastern lagoonal areas.

Another contrasting set of habitats is provided by lakes found on several of the islands, most of which have large populations of $B$. vittatum. A parallel sample was collected from a lake less than $100 \mathrm{~m}$ distant for 8 of the 17 shore sites, making a total of 25 samples. 
These lakes are actually sinkholes or dolines (Teichert, 1947), which differ in their exchange of water with the sea. The lakes on Long Island (site 1), Suomi Island (site 4), and Pelsaert Island (site 12) are shallow, with silty bottoms, and an impeded connection with the sea, as evidenced by their altered salinities and lag in tidal phase. Similarly, the lake on Serventy Island (site 3), although having a relatively solid bottom, has altered salinities and tidal lags. In contrast, the lakes on Keru Island (site 5) and Wooded Island (site 6) are separated from the sea by only a narrow cobble berm, and appear to experience fairly free subterranean tidal exchange, as evidenced by their near-ambient salinities and tidal oscillations. The exchange of water with the lakes on Post Office Island (site 8) and Arthur Island (site 9) is not as clear, but appears to be intermediate to the two groups classified above. Thus, the lake samples as a group provide a comparison of relatively isolated habitats, while differences among the lakes in their isolation allow a further test of subdivision.

\section{Electrophoresis}

The snails in each sample were frozen in the field in liquid nitrogen, and were later transferred to $-70^{\circ} \mathrm{C}$ pending electrophoresis. Enzymes were extracted by grinding 1 vol. hepatopancreas in 2 vol. of 10 per cent $(\mathrm{w} / \mathrm{v})$ sucrose containing 0.1 per cent $(\mathrm{v} / \mathrm{v})$ mercaptoethanol and 0.1 per cent $(w / v)$ bromophenol blue. Electrophoresis was carried out in horizontal starch gels. The buffer systems used were discontinuous triscitrate $/ \mathrm{NaOH}$ (Poulik) and continuous tris-EDTAborate (TEB), which are buffers 3 and 6, respectively, from Selander et al. (1971). From each sample, 45-48 individuals were examined for each of four polymorphic enzymes, representing five polymorphic gene loci: leucine aminopeptidase (E.C.3.4.-.-- Lap locus; TEB buffer); leucyl-proline peptidase (E.C.3.4.1.3; Lpp locus; TEB buffer); 6-phosphogluconate dehydrogenase (E.C.1.1.1.43; Pgd locus; TEB buffer); and valyl-leucine peptidase (E.C.3.4.1.3; Vlp1 and Vlp2 loci; Poulik buffer). At each locus, alleles were labelled numerically according to the electrophoretic mobility of their corresponding allozymes, relative to that of the most common allele, which was given a value of 100 . The allozymes of the Vlp1 locus migrated faster than those of $V l p 2$.

\section{Analyses}

Variation in allelic frequencies among samples for each locus was quantified using $F_{\mathrm{ST}}$, the standardized variance in allelic frequencies, which measures the proportion of allelic variation that is due to differences among populations (Wright, 1978). $F_{\mathrm{ST}}$ was calculated by the method of Weir \& Cockerham (1984). The jackknife procedure was used to obtain a mean and variance of $F_{\mathrm{ST}}$ over the five loci, allowing comparison of values obtained for different sets of samples (Reynolds et al., 1983). To test the significance of $F_{\mathrm{ST}}$, contingency chi-squared values were calculated, using the method of Workman \& Niswander (1970), in which $\chi^{2}=2 N F_{\mathrm{ST}}(k-1)$, where $N$ is the total sample size, and $k$ is the number of alleles; d.f. $=(k-1)(m-1)$, where $m$ is the number of samples. To ensure that the expected values were $\geq 4$, rare alleles were pooled; if as a group the pooled expected values were $<4$, the rare alleles were excluded from the test. In order to determine the apportionment of geographical variation within and among island groups, a hierarchical analysis of $F_{\mathrm{ST}}$ (Wright, 1978) was conducted, using the BIOsYs-1 computer package. Only the shore samples were included in this hierarchical analysis.

Pairwise comparisons between populations were made with Nei's (1978) unbiased genetic identity, calculated with Blosys- 1 . Because these genetic identities were calculated for this selected set of polymorphic loci, they should not be compared directly with values from other studies.

Variation within populations was expressed as observed heterozygosity, $H$. Departures of heterozygosity from Hardy-Weinberg, expectations were measured as $D=\left(H-H_{\mathrm{e}}\right) / H_{\mathrm{e}}$, where $H_{\mathrm{e}}$ is the expected number of heterozygotes in the sample. Overall values for $D$ were obtained by summing observed and summing expected numbers over samples. Statistical significance of the departures from Hardy-Weinberg expectations was tested with goodness-of-fit $\chi^{2}$.

\section{Results}

Allelic frequencies for all loci in each sample are shown in Table 1 . The most variable locus is Vlp2. Although this locus was polymorphic in all samples except Serventy lake (site $3 \mathrm{~L}$ ), the range of frequencies was very great: $0-0.98$ for the $V l p 2^{100}$ allele (Fig. 2). There is some regional pattern to this variation, with the islands in the Pelsaert Group having the highest frequencies of $V l p 2^{100}$. There is also much localized variation, with changes in allelic frequency over short distances in each of the three island groups. These differences, however, are among the lagoonal and lake samples of the eastern areas; in contrast, the western samples are relatively consistent in allelic frequencies, regardless of island group (Fig. 2; Table 2).

At each of the other four loci, one allele predominates throughout the Abrolhos Islands, but each locus 
Table 1 Allelic frequencies for five polymorphic enzymes in samples of Bembicium vittatum from the Abrolhos Islands. Location numbers refer to Fig. 1; western shore samples denoted by W, eastern shore samples by $\mathrm{E}$, and lake samples by $\mathrm{L}$

\begin{tabular}{|c|c|c|c|c|c|c|c|c|c|c|c|c|c|c|c|}
\hline \multirow[b]{2}{*}{ Sample } & \multicolumn{4}{|l|}{ Lap } & \multicolumn{2}{|l|}{$L p p$} & \multicolumn{2}{|l|}{$P g d$} & \multicolumn{4}{|l|}{ Vlpl } & \multicolumn{3}{|l|}{ Vlp2 } \\
\hline & 112 & 100 & 94 & 88 & 100 & 89 & 100 & 80 & 114 & 100 & 94 & 87 & 100 & 76 & 70 \\
\hline \multicolumn{16}{|l|}{ Wallabi group } \\
\hline 1E Long Is. & 0.00 & 1.00 & 0.00 & 0.00 & 1.00 & 0.00 & 1.00 & 0.00 & 0.00 & 1.00 & 0.00 & 0.00 & 0.46 & 0.54 & 0.00 \\
\hline 1L Long Is. & 0.00 & 1.00 & 0.00 & 0.00 & 1.00 & 0.00 & 1.00 & 0.00 & 0.00 & 1.00 & 0.00 & 0.00 & 0.23 & 0.77 & 0.00 \\
\hline 2W Lagoon Is. & 0.00 & 0.99 & 0.01 & 0.00 & 1.00 & 0.00 & 1.00 & 0.00 & .00 & 1.00 & 0.00 & 0.00 & 0.62 & 0.38 & 0.00 \\
\hline \multicolumn{16}{|l|}{ Easter group } \\
\hline 3E Serventy Is. & 0.00 & 1.00 & 0.00 & 0.00 & 1.00 & 0.00 & 1.00 & 0.00 & 0.10 & 0.90 & 0.00 & 0.00 & 0.18 & 0.82 & 0.00 \\
\hline 3L Serventy Is. & 0.06 & 0.94 & 0.00 & 0.00 & 1.00 & 0.00 & 1.00 & 0.00 & 0.15 & 0.85 & 0.00 & 0.00 & 0.00 & 00 & .00 \\
\hline 4E Suomi Is. & 0.00 & 1.00 & 0.00 & 0.00 & 1.00 & 0.00 & 1.00 & 0.00 & 0.08 & 0.92 & 0.00 & 0.00 & 0.17 & 0.83 & 0.00 \\
\hline 4L Suomi Is. & 0.31 & 0.69 & 0.00 & 0.00 & 0.92 & 0.08 & 1.00 & 0.00 & 0.28 & 0.71 & 0.00 & 0.01 & 0.35 & 0.65 & 0.00 \\
\hline 5E Keru Is. & 0.00 & 1.00 & 0.00 & 0.00 & 1.00 & 0.00 & 1.00 & 0.00 & 0.06 & 0.94 & 0.00 & 0.00 & 0.42 & 0.58 & 0.00 \\
\hline 5L Keru Is. & 0.22 & 0.78 & 0.00 & 0.00 & 1.00 & 0.00 & 1.00 & 0.00 & 0.04 & 0.96 & 0.00 & 0.00 & 0.31 & 0.69 & 0.00 \\
\hline 6E Wooded Is. & 0.00 & 1.00 & 0.00 & 0.00 & 1.00 & 0.00 & 1.00 & 0.00 & 0.00 & 1.00 & 0.00 & 0.00 & 0.70 & 0.30 & 0.00 \\
\hline 6L Wooded Is. & 0.00 & 1.00 & 0.00 & 0.00 & 1.00 & 0.00 & 1.00 & 0.00 & 0.02 & 0.98 & 0.00 & 0.00 & 0.71 & 0.27 & 0.02 \\
\hline 7W Rat Is. & 02 & 0.98 & 0.00 & 0.00 & 1.00 & 0.00 & 0.96 & 0.04 & 0.19 & 0.74 & 0.02 & 0.05 & 0.67 & 0.33 & 0.00 \\
\hline \multicolumn{16}{|l|}{ Pelsaert group } \\
\hline t Office Is. & 0.02 & 0.98 & 0.00 & 0.00 & 0.99 & 0.01 & 0.99 & 0.01 & 0.08 & 0.92 & 0.00 & 0.00 & 0.94 & 0.06 & 0.00 \\
\hline 8L Post Office Is. & 0.02 & 0.98 & 0.00 & 0.00 & 0.89 & 0.11 & 0.99 & 0.01 & 0.05 & 0.95 & 0.00 & 0.00 & 0.98 & 0.02 & 0.00 \\
\hline 9E Arthur Is. & 0.00 & 1.00 & 0.00 & 0.00 & 0.98 & 0.02 & 1.00 & 0.00 & 0.00 & 1.00 & 0.00 & 0.00 & 0.79 & 0.21 & 0.00 \\
\hline 9L Arthur Is. & 0.02 & 0.98 & 0.00 & 0.00 & 1.00 & 0.00 & 1.00 & 0.00 & 0.00 & 1.00 & 0.00 & 0.00 & 0.89 & 0.11 & 0.00 \\
\hline 10E Pelsaert Is., north & 0.01 & 0.99 & 0.00 & 0.00 & 0.85 & 0.15 & 0.98 & 0.02 & 0.01 & 0.99 & 0.00 & 0.00 & 0.90 & 0.10 & 0.00 \\
\hline 11E Fishhook Bay & 0.02 & 0.98 & 0.00 & 0.00 & 0.99 & 0.01 & 0.87 & 0.13 & 0.00 & 1.00 & 0.00 & 0.00 & 0.57 & 0.43 & 0.00 \\
\hline 12E Pelsaert Is., south & 0.00 & 1.00 & 0.00 & 0.00 & 0.78 & 0.22 & 0.91 & 0.09 & 0.00 & 1.00 & 0.00 & 0.00 & 0.54 & 0.46 & 0.00 \\
\hline 12L Pelsaert Is., south & 0.00 & 1.00 & 0.00 & 0.00 & 0.92 & 0.08 & 0.97 & 0.03 & 0.01 & 0.99 & 0.00 & 0.00 & 0.71 & 0.29 & 0.00 \\
\hline 13E Jon Jim Is. & 0.00 & 1.00 & 0.00 & 0.00 & 0.72 & 0.28 & 1.00 & 0.00 & 0.00 & 1.00 & 0.00 & 0.00 & 0.64 & 0.36 & 0.00 \\
\hline $14 \mathrm{~W}$ Gun Is. & 0.05 & 0.95 & 0.00 & 0.00 & 1.00 & 0.00 & 1.00 & 0.00 & 0.00 & 1.00 & 0.00 & 0.00 & 0.73 & 0.27 & 0.00 \\
\hline $15 \mathrm{~W}$ Seven Is. & 0.00 & 1.00 & 0.00 & 0.00 & 1.00 & 0.00 & 1.00 & 0.00 & 0.00 & 1.00 & 0.00 & 0.00 & 0.82 & 0.18 & 0.00 \\
\hline 16W Sweet I & 0.00 & 1.00 & 0.00 & 0.00 & 1.00 & 0.00 & 1.00 & 0.00 & 0.01 & 0.99 & 0.00 & 0.00 & 0.60 & 0.40 & 0.00 \\
\hline 17W Middle Is. & 0.01 & 0.96 & 0.00 & 0.03 & 1.00 & 0.00 & 1.00 & 0.00 & 0.02 & 0.98 & 0.00 & 0.00 & 0.64 & 0.36 & 0.00 \\
\hline
\end{tabular}

Table 2 Comparison of $F_{\mathrm{ST}}$ among different groups of samples of Bembicium vittatum

\begin{tabular}{lllllll}
\hline Set of sites & Lap & Lpp & Pgd & Vp1 & Vp2 & Mean \pm S.E. \\
\hline All samples & $0.031^{n}$ & $0.110^{* * *}$ & $0.022^{n}$ & $0.116^{* * *}$ & $0.258^{* * *}$ & $0.163 \pm 0.011$ \\
Western shore & $0.009^{n}$ & $0.000^{n}$ & $0.032^{n}$ & $0.167^{* * *}$ & $0.025^{*}$ & $0.030 \pm 0.002$ \\
Eastern shore & $0.002^{n}$ & $0.145^{* * *}$ & $0.025^{n}$ & $0.048^{n}$ & $0.258^{* * *}$ & $0.138 \pm 0.012$ \\
Lakes & $0.077^{* * *}$ & $0.040^{n}$ & $0.010^{n}$ & $0.140^{* * *}$ & $0.418^{* * *}$ & $0.277 \pm 0.017$ \\
\hline
\end{tabular}

${ }^{*}=P<0.05 ;{ }^{* * *}=P<0.001 ; n=$ valid $\chi^{2}$ could not be calculated.

shows some regional and localized variation. For example, Lap ${ }^{100}$ is fixed in nearly all samples, but the $L a p^{112}$ allele occurs at frequencies of $0.06-0.31$ in the lakes on Serventy, Suomi, and Keru islands, in the Easter Group (Fig. 2; Table 1). The variation at the
Vlp1 locus is also greatest in the Easter Group (Fig. 2). In contrast, at the $L p p$ locus allele 100 is fixed in all but one sample from the Wallabi and Easter groups, but in the Pelsaert Group, $L p p^{89}$ was found in several of the eastern populations, at frequencies as high as 0.28 


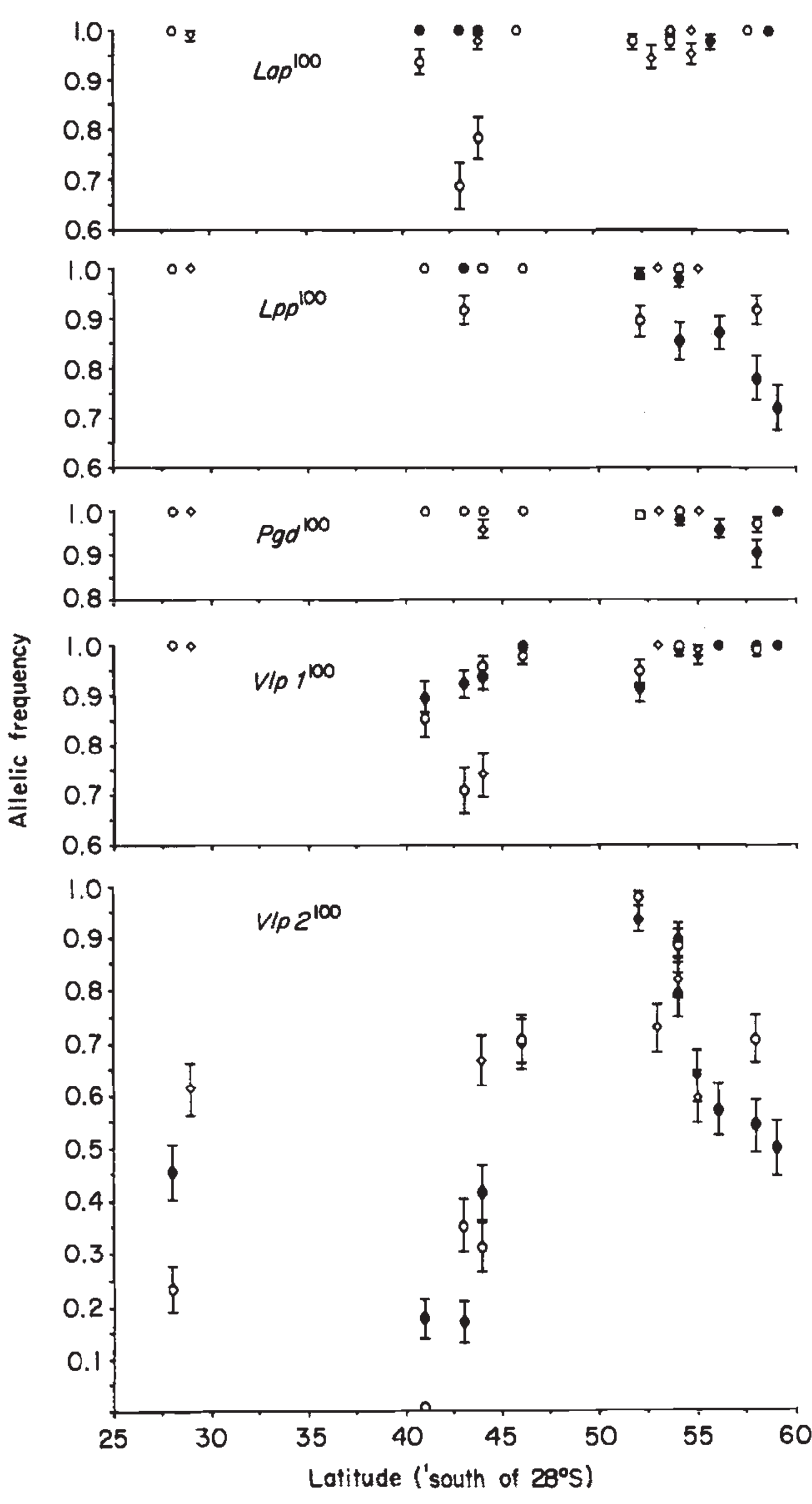

Fig. 2 Variation of allelic frequencies among samples from the Houtman Abrolhos Islands. $(\diamond)$ Western shore samples, (•) eastern shore samples, (O) lake samples. Vertical lines indicate approximate standard errors.

(Table 1). The Pgd locus shows a similar, but less extreme, pattern to that of $L p p: P g d^{100}$ is fixed in most samples, including all but one from the Wallabi and Easter groups, but there are localized low frequencies of $P g d^{l o O}$ in the eastern Pelsaert Group (Fig. 2).

The overall picture is clear despite the uniqueness of patterns of geographical variation for each locus. There is some regional variation, with particular alleles being associated with individual island groups: $L p p^{84}$ and $P g d^{80}$ were found almost exclusively in the Pelsaert Group, which also had the highest frequencies of $V l p 2^{l 00}$, whereas $L a p^{112}$ and $V l p 1^{114}$ were nearly restricted to the Easter Group (Table 1). Only the Wallabi Group lacked such genetic distinctness.

Overriding these regional differences, however, are substantial local variations within island groups. These include many differences between lake and shore samples, but we will first consider the differences among shore samples. For all of the loci examined except $V l p 2$, the variation in allelic frequencies among shore samples within one of the island groups encompasses that among all shore samples (Fig. 2). Even at the Vlp2 locus, differences among sites within groups are substantial, with the frequency of $V l p 2^{100}$ ranging from 0.17 to 0.70 in the Easter group and 0.54 to 0.94 in the Pelsaert group (Fig. 2). To quantify this comparison of variation within and among island groups, we performed a hierarchial analysis of $F_{\mathrm{ST}}$ : only 20 per cent of the geographical variation among shore populations is due to differences among island groups, with 80 per cent being among populations within groups.

The most interesting aspect of this variation among shore populations is that it is largely confined to the eastern islands; the populations from the more exposed western islands are relatively similar, regardless of island group. At the most variable locus, for example, the frequency of the $V_{l p 2^{100}}$ allele varies within the relatively narrow range of $0.60-0.82$ among the western populations, compared with 0.17-0.94 among the shore populations from the eastern islands (Fig. 2; Table 1). The average $F_{\mathrm{ST}}( \pm$ S.E.) is only $0.030 \pm 0.002$ among the western samples for all five loci examined, compared with $0.138 \pm 0.012$ among the eastern shore samples (Table 2).

In addition to this geographical variation among shore sites, there is an even greater variation associated with the lake populations. Differences between lake samples and the adjacent shore sites were widespread and often substantial, and were found at all loci except Pgd (Table 3). Among the most dramatic differences were the frequencies of $0.06,0.31$, and 0.22 for $L a p^{112}$ in the lake populations from Serventy, Suomi, and Keru islands, respectively, despite the absence of that allele from the adjacent shore samples. There is a tendency among the lake populations for those four lakes which are more isolated from the ocean $(1,3,4$, 12 ) to be less similar to their adjacent shore populations (average genetic identity \pm S.E. $=0.985 \pm 0.007$ ) than the populations from the four less isolated lakes $(0.997 \pm 0.003)$, although the differences was not quite significant $(t=1.659 ;$ d.f. $=6 ; 1$-tailed $P=0.074)$. The substantial differences between lake and adjacent shore samples are not consistent among sites. The lake samples do not represent a group of similar populations but show a substantial amount of variation amongst themselves, with an average $F_{\mathrm{ST}}$ of 
Table 3 Values of $\chi^{2}$ from comparisons of allelic frequencies between paired samples from lakes and adjacent shore populations of Bembicium vittatum. Each individual comparison has 1 d.f. n.t. indicates that a valid $\chi^{2}$ could not be calculated

\begin{tabular}{|c|c|c|c|c|c|}
\hline Site island & Lap & $L p p$ & $P g d$ & $V l p 1$ & $V l p 2$ \\
\hline 1 Long & n.t. & n.t. & n.t. & n.t. & $11.17^{* * *}$ \\
\hline 3 Serventy & n.t. & n.t. & n.t. & 0.76 & $18.65^{* * *}$ \\
\hline 4 Suomi & $35.55^{* * *}$ & $8.35^{* *}$ & n.t. & $13.68^{* * *}$ & $8.76^{* *}$ \\
\hline 5 Keru & $21.49^{* * *}$ & n.t. & n.t. & 0.42 & 1.60 \\
\hline 6 Wooded & n.t. & n.t. & n.t. & n.t. & 0.00 \\
\hline 8 Post Office & n.t. & $8.89^{* *}$ & n.t. & 0.69 & 2.09 \\
\hline 9 Arthur & n.t. & n.t. & n.t. & n.t. & 3.17 \\
\hline 12 Pelsaert & n.t. & $6.75^{* *}$ & 3.20 & n.t. & $5.29^{*}$ \\
\hline Summed $\chi^{2}$ & $57.04^{* * *}$ & $23.99^{* * *}$ & 3.20 & $15.55^{* *}$ & $50.73^{* * *}$ \\
\hline Summed d.f. & 2 & 3 & 1 & 4 & 8 \\
\hline
\end{tabular}

$*=P<0.05 ; * *=P<0.01 ; * * *=P<0.001$.

Table 4 Heterozygosities $(H)$ and departures from Hardy-Weinberg expectations $(D)$ for five polymorphic enzymes in samples of Bembicium vittatum from the Abrolhos Islands. Location numbers refer to Fig. 1. Western shore samples denoted by W, eastern shore samples by $\mathrm{E}$, and lake samples by $\mathrm{L}$

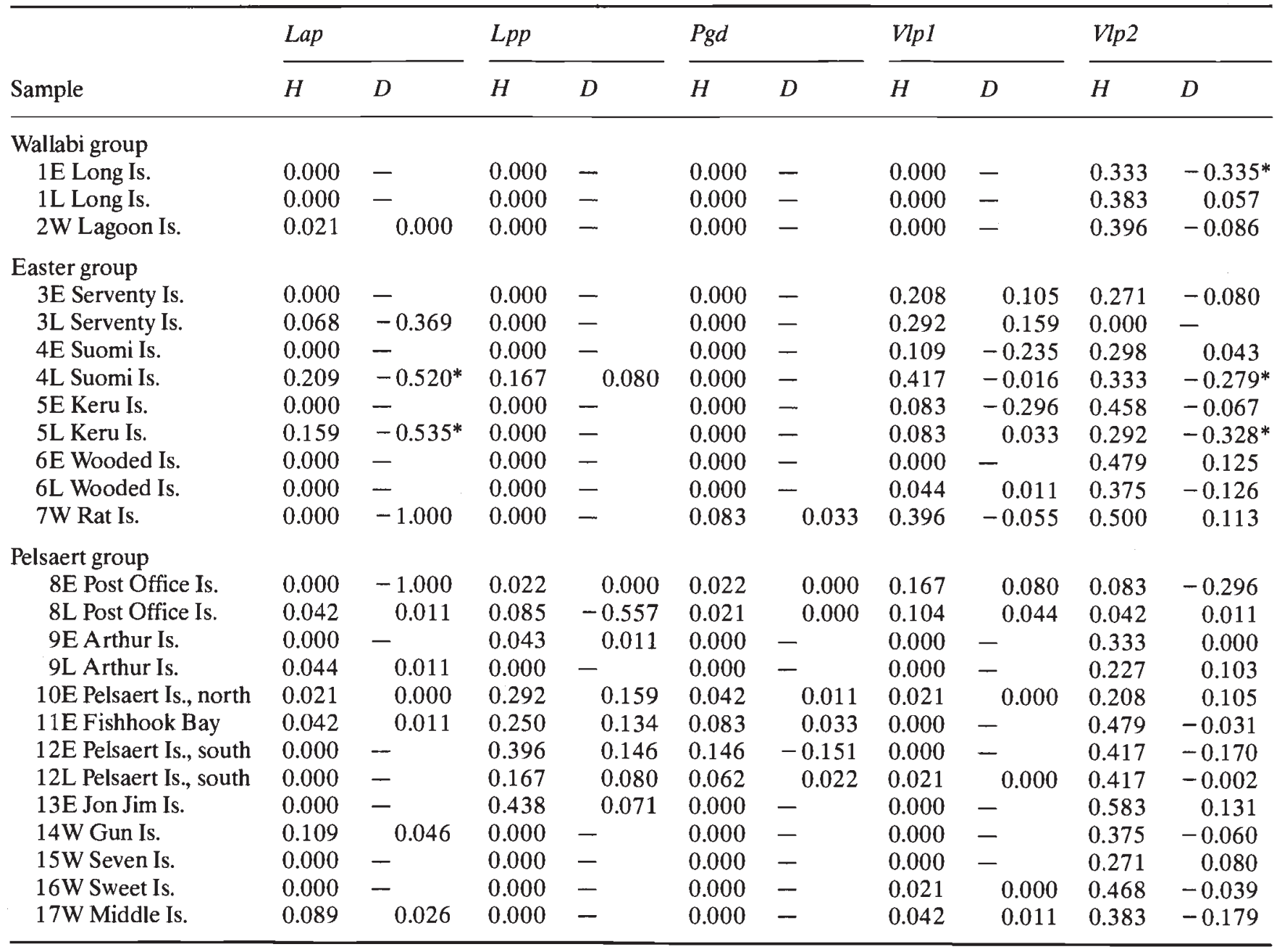

$*=P<0.05$. 
$0.277 \pm 0.017$ (Table 2), compared with $0.152 \pm$ 0.016 among their counterpart shore populations.

The observed heterozygosities and deviations from Hardy-Weinberg expectations for each locus in each sample are shown in Table 4. The average level of heterozygosity for the five polymorphic enzymes was as high in the lake samples as in the shore samples, $0.101 \pm 0.043$ (S.E.) and $0.097 \pm 0.061$, respectively. At the Lap locus, heterozygotes were found in five of the eight lake populations, but not in the eight adjacent shore populations. This trend was not consistent across loci, however, and no patterns of different levels of heterozygosity were found between lake and shore samples. Similarly, there were no detectable differences in heterozygosity between the western and eastern shore populations.

Most genotypic frequencies were close to expectation under Hardy-Weinberg equilibrium; of 43 tests in which the expected values were at least 4 , there were five significant $(P<0.05)$ departures from expectations. The significant departures were all deficits of heterozygotes, and they were confined to the Lap (two cases) and Vlp2 (three cases) loci (Table 4). Furthermore, the lake populations from Suomi and Keru islands accounted for all but one of the departures, as both Lap and Vlp2 showed large deficits of heterozygotes in these samples (Table 4). A possible explanation for this concordance would be the coexistence of two genetically distinct groups within each of these lakes. To test that possibility, we looked for linkage disequilibrium between $L a p$ and $V l p 2$ in the two lake samples with deficits of heterozygotes but there was no sign of the anticipated association between loci.

\section{Discussion}

The general picture that emerges for Bembicium vittatum is one of a high degree of genetic subdivision but with striking variation in the level of that subdivision. This combination reflects both the characteristics of the species and the importance of the environment in determining the amount of genetic differentiation. The level of genetic subdivision in $B$. vittatum is best appreciated by comparisons with other species. In contrast with the large overall $F_{\mathrm{ST}}$ of 0.163 found for $B$. vittatum, values for other marine invertebrates studied over much larger distances on the Western Australian coast range from 0.004 to 0.013 (Johnson \& Black, 1984, 1990; Watts et al., 1990). Ward (1990) summarized the studies of genetic diversity in species of Littorina, providing comparisons with other littorine gastropods, and finding an average $G_{\mathrm{ST}}$ (equivalent to $F_{\mathrm{ST}}$ ) of 0.047 for seven species with planktonic larvae. The geographical scale of these studies ranged from approximately $70 \mathrm{~km}$ to more than $1800 \mathrm{~km}$. In contrast, studies throughout Britain (distances on the order of $1000 \mathrm{~km}$ ) of three species which lack planktonic larvae have reported values of $F_{\mathrm{ST}}$ ranging from 0.131 to 0.188 . For Littorina saxatilis, the most extensively studied of the species which lack planktonic larvae, values of $F_{\mathrm{ST}}$ ranged from 0.070 on $1 \mathrm{~km}$ of shore, to 0.287 over distances of more than $10,000 \mathrm{~km}$. Thus, the overall value of 0.163 for the populations of $B$. vittatum from the Abrolhos Islands lies well within the range previously observed for species that lack planktonic larvae, but is especially high, given that the maximum distance between samples is only about $70 \mathrm{~km}$.

Although it is useful in gross comparisons among species, the overall average $F_{\mathrm{ST}}$ in Bembicium vittatum masks substantial variation in the degree of genetic subdivision among different sets of samples. Particularly striking is the effect of the lakes on genetic subdivision, with nearly a twofold increase in $F_{\mathrm{ST}}$ compared with the shore populations. Indeed, variation among the lake populations of $B$. vittatum is similar to that of land snails, which are renowned for their limited gene flow (e.g. Johnson, 1988; Johnson $e t$ al., 1988). The tendency for the apparently more isolated of the lake populations to have lower genetic similarities amongst themselves could reflect a gradation in the effectiveness of barriers to gene flow between lake and shore populations. Isolated populations, such as those in the lakes, would be expected to show greater genetic divergence due to both selective and random causes. One expectation from random genetic drift, however, is that isolated populations should have lower levels of polymorphism. This was not found in $B$. vittatum. Genetic drift is an especially unlikely explanation for the finding of the uncommon Lap $^{12}$ allele at moderate frequencies in three of the lake populations in the Easter Group. With this localized exception, however, differences between lake and shore samples are inconsistent, making them difficult to interpret as a result of selection. The possibility of differences occurring in the localized selection is particularly strong in the lakes because they are subject to greater variations in temperature and salinity, and experimental tests of possible selection would be worthwhile.

The contrast in the levels of subdivision among lake and shore populations is a clear example of the importance of barriers to gene flow. Note, however, the extremely low level of genetic divergence found among the shore samples from the western islands. The relative uniformity of these populations both within and between island groups is shown by their average value of $F_{\mathrm{ST}}$ of only 0.030 , nearly an order of magnitude 
smaller than that for the lake populations, and only one-fifth as large as that for the shore populations from the eastern islands. This low level of genetic differentiation must be explained by some combinations of high gene flow or strong uniform selection. Because of their position facing the open reef, these western populations are subject to a greater flow of water, which should both increase dispersal and decrease at least some environmental differences between sites. In the absence of details of the extent and direction of flow, and the consistency of patterns of flow over time, we cannot infer the actual potentials for gene flow between particular populations. Consequently, we cannot separate the relative contributions of gene flow and selection.

Nevertheless, the extremely low level of genetic divergence among the western samples has implications for the probable mode of development in $B$. vittatum. In a review of types of larval development in littorines, Mileikovsky (1975) lists B. vittatum (as Bembicium melanostoma) as having direct development. This is based on the observation of development past the veliger stage within benthic egg masses (Anderson, 1958). These egg masses did not hatch, however, so we cannot be certain that development was normal. As Reid (1988) points out, the relatively large protoconch of $B$. vittatum is characteristic of species with little or no planktotrophic development, but the conclusion that development is direct is questionable. The high degree of genetic uniformity among the western populations in the Abrolhos Islands strongly suggests that there is a short planktonic stage. Otherwise, it is difficult to reconcile the high degree of uniformity of the western populations with the high degree of genetic subdivision of the eastern populations.

Regardless of the actual length of the planktonic stage, if there is one, the contrast in levels of genetic subdivision from different habitats emphasizes the importance of environmental context. Such environinental effects have important implications both for the measurement of gene flow or genetic subdivision and for the understanding of evolutionary processes in the sea. On a broader geographical scale, it is well recognized that the magnitude of genetic differentiation varies within a species, often as a result of major barriers. A good example is the concordant pattern of genetic divergence found in many species between populations on the coasts of the Atlantic and the Gulf of Mexico, in the United States, representing a major biogeographic split (e.g. Johnson, 1975; Reeb \& Avise, 1990). Of greater interest in terms of ongoing influences on genetic subdivision are examples of localized disruptions to gene flow. For example, the milkfish Chanos chanos shows very little genetic differentiation across much of the Pacific Ocean, but is genetically subdivided within the Hawaiian Islands, probably because of localized effects on the flow of currents (Winans, 1980). An even clearer example of the importance of particular types of environment on genetic subdivision is the pattern of variation in snapper, Chrysophrys auratus, in Australia. Although there is very little genetic divergence among populations over thousands of kilometres along the outer coast, there are genetically divergent populations in the embayments of Shark Bay in Western Australia, Spencer Gulf in South Australia, and Port Phillip Bay in Victoria (Johnson et al., 1986; Richardson et al., 1986). The findings for Bembicium vittatum show that environmental differences can affect genetic subdivision on a much smaller geographic scale. Taken together, these examples of localized disruptions to gene flow indicate that evolutionary changes in marine species are more likely to result from peculiar local conditions that favour isolation, than from the more typical, highly connected populations.

A great advantage of the Abrolhos Islands for genetic studies is that different habitats can be sampled over the same spatial scale, both within and between island groups. Thus, the contrasting levels of genetic subdivision in Bembicium vittatum reflect different types of environment, rather than biogeographic histories or geographically defined areas of subdivision. Although a similar effect of environmental conditions has been found in arthropods inhabiting caves (Caccone, 1985), such variation in the levels of gene flow has received little attention. It is clear that estimates of the average levels of subdivision or gene flow may be misleading, as they mask biologically significant variation in the degree of connectedness of populations. As genetic studies are used increasingly to make inferences about levels of gene flow, it is important to take account of this heterogeneity, and to recognize that gene flow depends upon environmental conditions, even in the marine environment.

\section{Acknowledgements}

We would like to thank Dr Bruce Hatcher for introducing us to the Houtman Abrolhos Islands, for his stimulating help in the field, and for perceptive comments on the manuscript. Ms Robyn Watts provided assistance in the laboratory and helpful discussion of the manuscript. Financial support was provided by the Australian Research Council. 


\section{References}

ANDERSON, H. 1958. The gastropod genus Bembicium Phillipi. Aust. J. Mar. Freshwat. Res., 9, 546-568.

BEHRENS YAMADA, S. 1989. Are direct developers more locally adapted than planktonic developers? Mar. Biol., 103, 403-411.

BERGER, E. 1973. Gene-enzyme variation in three sympatric species of Littorina. Biol. Bull. Mar. Biol. Lab., 145, 83-90.

BURTON, R. s. 1983. Protein polymorphisms and genetic differentiation of marine invertebrate populations. Mar. Biol. Lett., 4, 193-206.

CACCONE, A. 1985. Gene flow in cave arthropods: a qualitative and quantitative approach. Evolution, 39, 1223-1235.

CRISP, D. J. 1978. Genetic consequences of different reproductive strategies in marine invertebrates. In: Battaglia, B. and Beardmore, J. A. (eds), Marine Organisms, Genetics, Ecology, and Evolution, Plenum Press, New York, pp. 257-273.

HATCHER, B. G. 1985. Ecological research at the Houtmans Abrolhos: High latitude reefs of Western Australia. Proc. Fifth Int. Coral Reef Congr., 6, 291-297.

HEDGECOCK, D. 1986. Is gene flow from pelagic larval dispersal important in the adaptation and evolution of marine invertebrates? Bull. Mar. Sci., 39, 550-564.

JANSON, K. 1987. Allozyme and shell variation in two marine snails (Littorina, Prosobranchia) with different dispersal abilities. Biol. J. Linn. Soc., 30, 245-256.

JOHNSON, M. S. 1975. Biochemical systematics of the atherinid genus Menidia. Copeia, 1975, 662-691.

JOHNSON, M. S. 1988. Founder effects and geographic variation in the land snail Theba pisana. Heredity, 61, 133-142.

JOHNSON, M. S. AND BLACK, R. 1984. Pattern beneath the chaos: the effect of recruitment on genetic patchiness in an intertidal limpet. Evolution, 38, 1371-1383.

JOHNSON, M. S. AND BLACK, R. 1990. Genetic divergence of venerid clams in Shark Bay. In: Berry, P., Bradshaw, S. D. and Wilson, B. R. (eds), Research in Shark Bay, Western Australian Museum, Perth, pp. 159-168.

JOHNSON, M. S., CLARKE, B. AND MURRAY, J. 1988. Discrepancies in the estimation of gene flow in Partula. Genetics, 120, 233-238.

JOHNSON, M. S., CREAGH, S. AND MORAN, M. 1986. Genetic subdivision of stocks of snapper, Chrysophrys unicolor, in Shark Bay, Western Australia. Aust. J. Mar. Freshwat. Res., 37, 337-345.

KNIGHT, A. J., HUGHES, R. N. AND WARD, R. D. 1987. A striking example of the founder effect in the mollusc Littorina saxatilis. Biol. J. Linn. Soc., 32, 417-426.

MILEIKOvskY, S. A. 1975. Types of larval development in Littorindae (Gastropoda: Prosobranchia) of the world ocean, and ecological patterns of their distribution. Mar. Biol., 30, 129-135.

NEI, M. 1978. Estimation of average heterozygosity and genetic distance from a small number of individuals.
Genetics, 89, 583-590.

REEB, C. A. AND AVISE, J. C. 1990. A genetic discontinuity in a continuously distributed species: mitochondrial DNA in the American oyster, Crassostrea virginica. Genetics, 124, 397-406.

REID, D. G. 1988. The genera Bembicium and Risellopsis (Gastropoda: Littorinidae) in Australia and New Zealand. Rec. Aust. Mus., 40, 91-150.

REYNOLDS, J., WEIR, B. S. AND COCKERHAM, C. C. 1983. Estimation of the coancestry coefficient: basis for a short-term genetic distance. Genetics, 105, 767-779.

RICHARDSON, B. J., BAVERSTOCK, P. R. AND ADAMS, M. 1986. Allozyme Electrophoresis. Academic Press, Sydney.

SCHELTEMA, R. S. 1971. Larval dispersal as a means of genetic exchange between geographically separated populations of shallow water benthic marine gastropods. Biol. Bull. Mar. Biol. Lab., 140, 284-322.

SCHELTEMA, R. S. 1978. On the relationship between dispersal of pelagic veliger larvae and the evolution of marine prosobranch gastropods. In: Battaglia, B. and Beardmore, J. A. (eds), Marine Organisms, Genetics, Ecology, and Evolution, Plenum Press, New York, pp. 303-322.

SELANDER, R. K., SMITH, M. H., YANG, S. H., JOHNSON, W. E. AND GENTRY, J. B. 1971. Biochemical polymorphism and systematics in the genus Peromyscus. I. Variation in the old-field mouse (Peromyscus polionotus). Stud. Genet., 6, 49-90.

SLATKIN, M. 1985. Gene flow in natural populations. Ann. Rev. Ecol. Syst., 16, 393-430.

SLATKIN, M. 1987. Gene flow and the geographic structure of natural populations. Science, 236, 787-792.

TEICHERT, C. 1947. Contributions to the geology of Houtman's Abrolhos, Western Australia. Proc. Linn. Soc. N.S.W., 71, 145-196.

WAPLES, R. S. 1987. A multispecies approach to the analysis of gene flow in marine shore fishes. Evolution, 41, 385-400.

WARD, R. D. 1990. Biochemical genetic variation in the genus Littorina (Prosobranchia: Mollusca). Hydrobiologia, 193, 53-69.

WATTS, R. J., JOHNSON, M. S. AND BLACK, R. 1990. Effects of recruitment on genetic patchiness in the urchin Echinometra mathaei in Western Australia. Mar. Biol., 105, 145-151.

WEIR, B. S. AND COCKeRHAM, C. C. 1984 . Estimating $F$-statistics for the analysis of population structure. Evolution, 34, $1358-1370$.

WINANS, G. A. 1980. Geographic variation in the milkfish Chanos chanos. I. Biochemical evidence. Evolution, 38, 558-574.

WORKMAN, P. L. AND NISWANDER, J. D. 1970. Population studies on southwestern Indian tribes. II. Local genetic differentiation in the Papago. Am. J. Hum. Genet., 22, 24-29.

WRIGHT, s. 1978. Evolution and the Genetics of Populations. Vol. 4. Variability Within and Among Natural Populations, University of Chicago Press, Chicago. 